Research.

\title{
THE INFLUENCE OF APPLICATION SYSTEM QUALITY CONTROL IN THE PERFORMANCE OF AUDITORS (EMPIRICAL STUDIES) ABC KAP IN SOUTH JAKARTA IN 2009 - 2013
}

\author{
By: \\ Blasius Febriyanto Trisno Saputro and Dwi Asih Surjandari
}

\begin{abstract}
This study has the objective to determine the effect the independence, professionalism, professional ethics and integrity of client understanding of the performance of the auditors on an empirical study of the public accounting firm $A B C$ in South Jakarta. The method used in sampling is convenience sampling. The number of questionnaires distributed 150 questionnaires. However, the back and can be used for further analysis of 120 questionnaires. Analysis of the data is to use multiple linear regression coefficient of determination see, the value of $F$ statistics and statistical $t$. Results of this study showed that the independence, professionalism and ethics of the profession positive effect on the performance of auditors while understanding client integrity negative effect on the performance of auditors.
\end{abstract}

Keywords: Independent, Profesionalisme, Ethic of Professional, Client Integrity and Auditors Performance

\section{INTRODUCTION}

Liberalization accountant ASEAN services within the framework of AFTA 2015, apparently no problem for propession lightly. Intense competition with neighboring accountant on the field, it is not simple problems, when referring to the strength of position in an asean map. System quality control one factor for accountant and accountant office has made a person or company be in nadir maturity and application of moral in developing business. And whether that is because demands or as a hence firm or clients needing an office public accountant. The accountant public services cannot be separated from the economic activities more advanced entity that required to explain the accountability and transparency (Novi, and friends, 2013).

An essential part of quality control system that is both integrity and objectivity the public accountant started doubtful. Period of time in 10 this year (2004 to 2014) there are some office accountant frozen and given administrative sanctions by the finance minister of Indonesia. The problem is linked doubtful integrity and objectivity in running quality control system applied in implementing the job and breaking standard auditing (SA) and accountant professional standards public (SPAP) that had taken and implemented .

The main characteristics of a profession accountant the public is independence. A auditors must have good personality, adequate knowledge, and the skills in the field (Sukriah, dkk., 2009) independence and objectivity of profession (Cezair Audit, 2010). Besides independence and professionalism factors that impact on the performance of auditors is ethics profession. Herawaty and Susanto (2009) said that ethics the should code of conduct accountant Indonesia, the governing behavior relations between public accountant and his colleagues and the profession with the community.

Research on quality control system in kap. And the application of independence, professionalism and ethics profession has examined by M. Ikbal (2008), K.M. Dinata dkk (2013) and Novi dkk (2013). M. Ikbal presents research that the implementation of quality control system (public policy, personnel, management audit, inspection and review) at an institute of non affiliation in Jakarta the results the implementation level quality control system at the public accountant in Jakarta not affiliated high.

This research replicate of research K. M. Dinata (2013) and researchers add one variable in research and understanding integrity clients who is concern that integrity client is make good

Blasius Febriyanto Trisno Saputro and Dwi Asih Surjandari: The Influence of Application System Quality Control in The Performance of Auditors (Empirical Studies) ABC Kap in South Jakarta in 2009 - 2013 
governance which is GCG who play an important role in control system quality and management will create a more open and transparent. Research gap this research among other Gunawan (according to 2006) assess quality control namely the performance of auditors not influenced by the independence of and in the concept of the understanding of clients and this is according to research Trisnaningsih (2007) performance of auditors not significant impact on this concept. While this research add the variable because of kap. On understanding of integrity clients or element of a crucial where kap.And the auditors can evaluate over more information in the top clients and can consider the state or special attention or having risk who do not fair. So impact on performance in the hood auditor (bulletin public accountant, 2010). The difference the study to research conducted K. M. Dinata dkk such as 1 ) the influence independence of, professional and ethics profession of the performance of the kap auditors. In Bali, while in this research using empirical kap studies. ABC in south Jakarta by a period of the year 2009 - 2013.2 ) research K. M. Dinata dkk there are three independent variable the independence of, professional and ethics profession while this research using four independent variable by adding one variable independent namely understanding integrity clients. The purpose and contribution research:

1. The application of quality control system in independence of of the performance of the auditors has been applied ABC kap.

2. The application of quality control system in professional of the performance of the auditors has been applied ABC kap.

3. The application of quality control system in ethics profession of the performance of the auditors has been applied by the ABC kap.

4. The application of sisten quality control in understanding integrity clients of the performance of the auditors has been applied the Abc kap.

\section{LIBRARY REVIEW, RESEARCH PARADIGM, AND HYPOTHESES OF THE RESEARCH}

1. Theoretical

Good corporate governance (GCG) according national Governance Committee (KNKG, 2006 ) is One of pillars the market economy system Corporate governance closely related to the good faith of the companies that execute them or business climate in a country. Implementation of GCG encourage the creation of fair competition and business conducive climate. Good Corporate Governance is defined as a system that regulates and controls the company to create value added (value added) to all stakeholders.

2. Theory Auditing is a guideline in the implementation of the audit that is normative. An auditor in performing the audit must implement audit procedures in accordance with the standards accepted by the public. Mautz and Sharaf (1993: 80) states that there are five concepts in auditing theory that evidence, audit due care, fair presentation, independence, and ethical conduct .

3. The Theory Atributsi

A theory that explain a person behavior . The theory is based on how someone explain the behavior of others or oneself. Fritz Heider (1958) said that a person behavior it could because the internal factor (called the attribution) internal and external caused by factor (the attribution external). the internal factor for example the ability, knowledge and business, while factor external can be a chance, and also the environment.

4. Quality Control System

Quality control system constituting a standard which should be owned by an office public accountant and used as guidelines in terms of accounting and implementation audits (anonymous, 2000). Every professional the auditors have to invoke themselves with the standards of existing as a measure of their performance (Arens et al, 2005). While formal approach used in controlling the implementation of an audit is quality control system. (Flint, 1988; Arens et al, 2005; IAI, 2001). Where according to Arens, Elder and Beasley (2005) there are five elements of system quality control;

a. independence, integrity and obyectivity,

b. personal management,

c. acceptance and continuation of clients and engagements,

d. enggagement performance, and

Blasius Febriyanto Trisno Saputro and Dwi Asih Surjandari: The Influence of Application System Quality Control in The Performance of Auditors (Empirical Studies) ABC Kap in South Jakarta in 2009 - 2013 
e. monitoring.

\section{RESEARCH METHODOLOGY}

A. The kind of research in carrying out this study, researchers used the kind of research causal with a view test that hypothesis about the effects of the four the independent variable against one the dependent variable.

B. The definition and operation variable

The dependent variable or variable bound is variable that influenced who come as a result, as a result of the variable free. The dependent variable for here is the performance of an auditor. The independent variable or variable free was an variables affecting or were the revisions or the emergence of signs of the dependent variable. The independent variable here is the independence of the, professionalism The professional ethics and understanding the integrity of clients.

C . The Measurement of Variable

The measurement of a variable in this research is by the scale of the interval which is where the auditors are asked to choose one of the answers in quitionaire that is consistent with an alternative perseptions among the answer which has been provided.

D. The population and sample research

The sample technique research uses the convenience of sampling the election of sampling based on ease, so researchers can give the questionnaire handing out kuiesioner the direct impact on all kap auditors ABC in Jakarta because this case studies and auditors which is chosen and filling is experienced audit and study the case in kap. ABC five years 2009 to 2013 with various cases audit handled and client him and tenure auditors.

E. Data collection techniques

Engineering data collection is by spreading the questionnaire to auditors in the hood. $A B C$ in jakarta to get primary data with spread around 150 the questionnaire in the form of questions written done directly by researchers to auditors hood. $A B C$ in south Jakarta and also with direct observation in kap. ABC in south Jakarta.

\section{F. Analysis Methods}

Data analysis is a process simplification data into a more easily be read and interpreted. Using quantitative methods expected to get the measurement result of an accurate given respondents so that data shaped the figure can be processed by using statistics method.

\section{THE RESULTS OF ANALYSIS AND DISCUSSION}

\section{A. Descriptive Statistics}

This report is written with empirical studies the office public accountant $A B C$ in Jakarta the past 2009 to 2013. This research using convenience of sampling and researchers has spread the questionnaire 150 copies for all an auditor who considered represent in range the past empirical studies above the office public accountant $A B C$ in Jakarta, who responded by 120 auditor (response rate by 80 percent), where to 120 kuisioner that have been fitted by each respondents qualified for analysis Research is done by empirical study in kantor akuntan publik ABC in Jakarta the past 2009 to 2013. 
Table 1.

Details of the division of the questionnaire

\begin{tabular}{|l|c|}
\hline \multicolumn{1}{|c|}{ Description } & Amount \\
\hline Questionnaires were distributed & 150 \\
\hline Questionnaires were returned & 120 \\
\hline Questionnaires which can be processed & 120 \\
\hline The rate of return (response rate) & $80 \%$ \\
\hline
\end{tabular}

Source: Primary data examined

Table 1 above shows that 150 questionnaires by researchers to the auditors in KAP $A B C$ in Jakarta used as a source of research and processed as the primary of data 120 or by $80 \%$

Table 2.

Characteristics of Respondents

\begin{tabular}{|l|c|c|}
\hline \multicolumn{1}{|c|}{ Description } & $\begin{array}{c}\text { Frequency } \\
\text { Number }\end{array}$ & Procentage \\
\hline Number of respondents & 120 & $100 \%$ \\
\hline Gender & 75 & $62,5 \%$ \\
Male & 45 & $37,5 \%$ \\
Female & & \\
\hline Education : & 15 & $12,5 \%$ \\
S2 & 95 & $79,2 \%$ \\
S1 & 10 & $8,3 \%$ \\
D3 & & \\
Jabatan : & 2 & $1,7 \%$ \\
Manager & 10 & $8,3 \%$ \\
Supervisor & 80 & $66,7 \%$ \\
Senior Auditor & 28 & $23,3 \%$ \\
Junior Auditor & & \\
\hline Length of work: & 30 & $25 \%$ \\
> 5 Tahun & 55 & $45,8 \%$ \\
3 - 5 Tahun & 35 & $29,2 \%$ \\
< 3 Tahun & &
\end{tabular}

Source: Primary data examined

Blasius Febriyanto Trisno Saputro and Dwi Asih Surjandari: The Influence of Application System Quality Control in The Performance of Auditors (Empirical Studies) ABC Kap in South Jakarta in 2009 - 2013 
Table 3

Descriptive Statistics

\begin{tabular}{|l|r|r|r|r|r|}
\hline & $\mathrm{N}$ & Minimum & Maximum & Mean & $\begin{array}{c}\text { Std. } \\
\text { Deviation }\end{array}$ \\
\hline Independent (X1) & 120 & 2.09 & 4.91 & 3.5470 & .86782 \\
Professionalism & 120 & 1.93 & 5.00 & 3.5217 & .86465 \\
(X2) & 120 & 2.14 & 5.00 & 3.6554 & .85592 \\
Ethics (X3) & 120 & 1.88 & 5.00 & 3.5833 & .89588 \\
Integrity (X4) & 120 & 1.83 & 4.92 & 3.5632 & .84812 \\
Kinerja (Y) & 120 & & & & \\
Valid N (listwise) & & & & \\
\hline
\end{tabular}

\section{B. Test the quality of data}

1. Validity Test

Test validity used to measure legal or valid whereabouts of a kuisioner. A measuring instrument said valid if it is said carefully about variable measured.

Table 4.

Validity Test Pearson Correlation

Correlations

\begin{tabular}{|c|c|c|c|c|c|c|}
\hline & & $\begin{array}{r}\text { Independensi } \\
(\mathrm{X} 1)\end{array}$ & $\begin{array}{r}\text { Profesionalisme } \\
(\mathrm{X} 2)\end{array}$ & Etika (X3) & $\begin{array}{r}\text { Integritas } \\
(\mathrm{X} 4)\end{array}$ & Kinerja $(\mathrm{Y})$ \\
\hline $\begin{array}{l}\text { Independ } \\
\text { ent (X1) }\end{array}$ & $\begin{array}{c}\text { Pearson Correlation } \\
\text { Sig. (2-tailed) } \\
\text { N }\end{array}$ & $\begin{array}{c}1 \\
120\end{array}$ & $\begin{array}{l}.303^{* *} \\
.001 \\
120\end{array}$ & $\begin{array}{l}.213^{*} \\
.019 \\
120\end{array}$ & $\begin{array}{l}.646^{* *} \\
.000 \\
120\end{array}$ & $\begin{array}{l}.369^{* *} \\
.000 \\
120\end{array}$ \\
\hline $\begin{array}{l}\text { Professio } \\
\text { nalism } \\
\text { (X2) }\end{array}$ & $\begin{array}{c}\text { Pearson Correlation } \\
\text { Sig. (2-tailed) } \\
\text { N }\end{array}$ & $\begin{array}{l}.303^{* *} \\
.001 \\
120\end{array}$ & $\begin{array}{c}1 \\
120\end{array}$ & $\begin{array}{l}.193^{*} \\
.034 \\
120\end{array}$ & $\begin{array}{l}.675^{*} \\
.000 \\
120\end{array}$ & $\begin{array}{l}.319^{*} \\
.000 \\
120\end{array}$ \\
\hline Ethics(X3) & $\begin{array}{c}\text { Pearson Correlation } \\
\text { Sig. (2-tailed) } \\
\text { N }\end{array}$ & $\begin{array}{l}.213^{*} \\
.019 \\
120\end{array}$ & $\begin{array}{l}.193^{*} \\
.034 \\
120\end{array}$ & $\begin{array}{c}1 \\
120\end{array}$ & $\begin{array}{l}.550^{*} \\
.000 \\
120\end{array}$ & $\begin{array}{l}.314^{* *} \\
.000 \\
120\end{array}$ \\
\hline $\begin{array}{l}\text { Integrity } \\
\text { (X4) }\end{array}$ & $\begin{array}{l}\text { Pearson Correlation } \\
\text { Sig. (2-tailed) } \\
\text { N }\end{array}$ & $\begin{array}{l}.646^{* *} \\
.000 \\
120\end{array}$ & $\begin{array}{l}.675^{* *} \\
.000 \\
120\end{array}$ & $\begin{array}{l}.550^{*+} \\
.000 \\
120\end{array}$ & $\begin{array}{c}1 \\
120\end{array}$ & $\begin{array}{l}.373^{*} \\
.000 \\
120\end{array}$ \\
\hline $\begin{array}{c}\text { Performan } \\
\text { ce }(Y)\end{array}$ & $\begin{array}{c}\text { Pearson Correlation } \\
\text { Sig. (2-tailed) } \\
\text { N }\end{array}$ & $\begin{array}{l}.369^{* *} \\
.000 \\
120\end{array}$ & $\begin{array}{l}.319^{* *} \\
.000 \\
120\end{array}$ & $\begin{array}{l}.314^{* *} \\
.000 \\
120\end{array}$ & $\begin{array}{l}.373^{* *} \\
.000 \\
120\end{array}$ & 120 \\
\hline
\end{tabular}

Score Correlated Item - total; Correlation with the calculated $r$ table. If $r$ is bigger than $r$ table and a positive value, the item or question or these indicators declared invalid.

Blasius Febriyanto Trisno Saputro and Dwi Asih Surjandari: The Influence of Application System Quality Control in The Performance of Auditors (Empirical Studies) ABC Kap in South Jakarta in 2009 - 2013 
A. Reliability test

Table 6.

Indepence Reability test

Reliability Statistics

\begin{tabular}{|c|c|}
\hline Cronbach's Alpha & $\mathrm{N}$ of Items \\
\hline .929 & 11 \\
\hline
\end{tabular}

Table 7.

Profesionalism Reliability Statistics test

\begin{tabular}{|c|c|}
\hline Cronbach's Alpha & N of Items \\
\hline .948 & 15 \\
\hline
\end{tabular}

Table 8.

Professional ethics Reliability Statistics Test

\begin{tabular}{|c|c|}
\hline Cronbach's Alpha & N of Items \\
\hline .943 & 14 \\
\hline
\end{tabular}

Table 9.

Reliability test Comprehension Integrity Client

Reliability Statistics

\begin{tabular}{|c|c|}
\hline Cronbach's Alpha & N of Items \\
\hline .921 & 8 \\
\hline
\end{tabular}

Tabel 10

Performance Auditor Reliability test

Reliability Statistics

\begin{tabular}{|c|c|}
\hline Cronbach's Alpha & N of Items \\
\hline .927 & 12 \\
\hline
\end{tabular}

The results of calculation above shows that the instrument for $X_{1}, X_{2}, X_{3}, X_{4}$ and $Y$ have the reliability figures are very high (Cronbach's alpha $\geq 0.70$ ), because according Nunnaly (1994) and Hinkle (2004) or an index commonly used in social

Blasius Febriyanto Trisno Saputro and Dwi Asih Surjandari: The Influence of Application

System Quality Control in The Performance of Auditors (Empirical Studies) ABC Kap in South Jakarta in $2009-2013$ 
studies, if the figure Cronbach's Alpha ( $\alpha$ ) above 0.70 indicates that the instrument to measure the construct or variable is reliable.

\section{B. Classical Assumption Test}

1. Test Multicolinearity

Table 11.

Test Multicolinearity

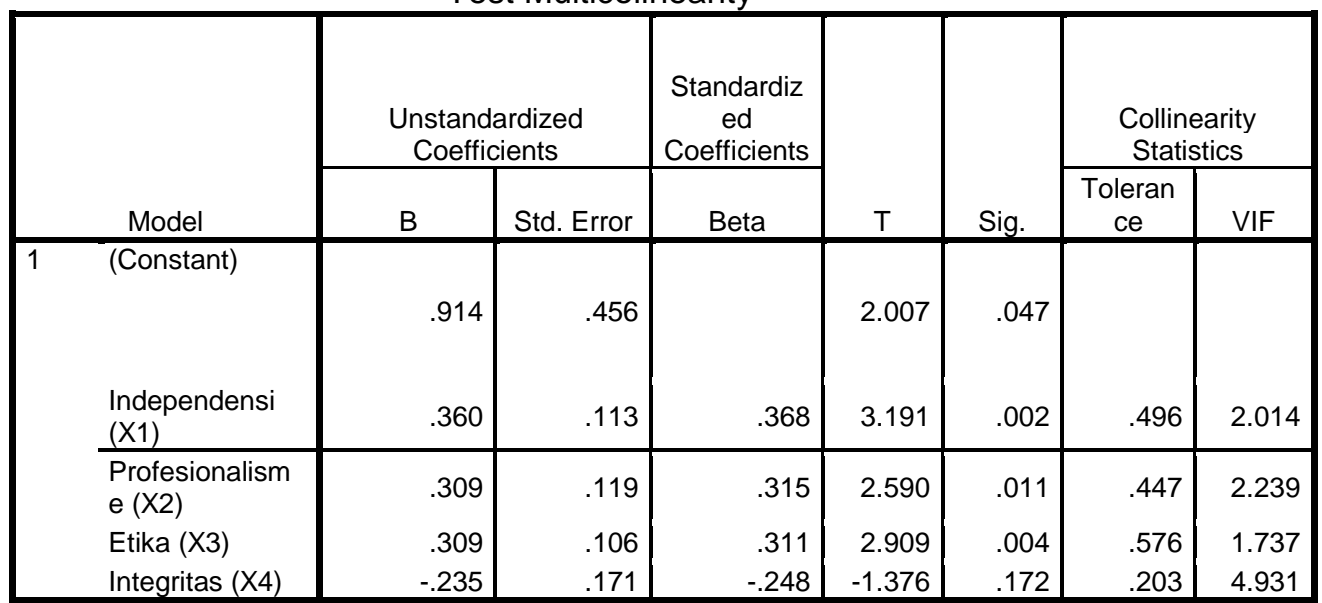

Source: Primary data examined

According to VIF value under 10 , and tolerance value $>0.1$, no multicolinearity independen variable.

2. Heteroscedastisity test

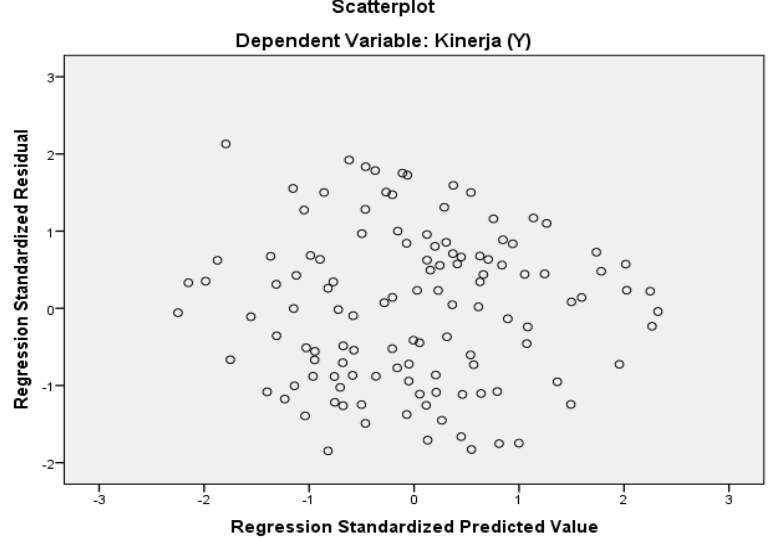

Based on the scatterplot diagram above, the data seen that do not form a particular pattern (scattered irregularly). It means free of problems heteroscedastisity empirically models. 
3. Normality data test

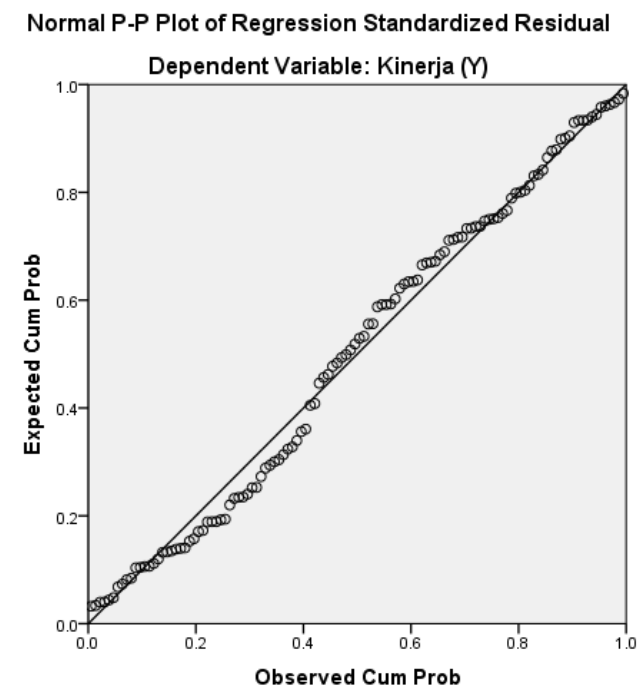

Based on the graphic display P-plot it can be concluded that the dots spread around the diagonal line, and its distribution follows the direction of the diagonal.

Table 12

Kolmogorov-Smirnof

One-Sample Kolmogorov-Smirnov Test

\begin{tabular}{|cc|c|}
\hline & & $\begin{array}{c}\text { Standardized } \\
\text { Residual }\end{array}$ \\
\hline \multirow{2}{*}{ Normal Parameters ${ }^{\mathrm{a}, \mathrm{b}}$} & Mean & 120 \\
& .0000000 \\
Most Extreme Differences & Std. Deviation & .98304962 \\
& Absolute & .069 \\
& Positive & .069 \\
& Negative & -.056 \\
\cline { 3 - 3 } Test Statistic & & .069 \\
Asymp. Sig. (2-tailed) & & $.200^{\mathrm{c}, \mathrm{d}}$ \\
\hline
\end{tabular}

\section{Hipotesis:}

$\mathrm{H}_{0}$ : data on normal distribution

$\mathrm{H}_{1}$ : data not normal distribution

If the probability (sig) $>0.05$ then $\mathrm{H}_{0}$ is not rejected if the probability (sig) $<0.05$ then $\mathrm{H}_{0}$ is rejected. Based in Table 12 in sig value $=0.200>0.05$, so $\mathrm{H}_{0}$ is not rejected, which that mean data residual normal distribution.

Blasius Febriyanto Trisno Saputro and Dwi Asih Surjandari: The Influence of Application System Quality Control in The Performance of Auditors (Empirical Studies) ABC Kap in South Jakarta in 2009 - 2013 
D. Hypothesis testing

1. Determination coeficein test $\left(\mathrm{R}^{2}\right)$

Table 13.

Determination coeficein test $\left(\mathbf{R}^{2}\right)$

\begin{tabular}{|c|c|c|c|c|}
\hline \multicolumn{5}{|c|}{ Model Summary ${ }^{b}$} \\
\hline Model & $\mathrm{R}$ & R Square & $\begin{array}{l}\text { Adjusted R } \\
\text { Square }\end{array}$ & $\begin{array}{l}\text { Std. Error of } \\
\text { the Estimate }\end{array}$ \\
\hline 1 & $.491^{a}$ & .241 & .215 & .75145 \\
\hline
\end{tabular}

SPSS output display models of summary, the magnitude Rated R square is 0.241 , meaning $24.1 \%$ of the variation auditor performance can be explained by the variation of the four independent variables independence, professionalism, professional ethics and integrity of client understanding, while the remaining $75.9 \%$ is explained by other factors outside the model.

2. Simultance significance test ( $F$ statistic test )

Table 14

Simultance Significance Test (uji statistik F)

ANOVA ${ }^{\mathrm{a}}$

\begin{tabular}{|cc|c|c|c|c|c|}
\hline \multicolumn{1}{|c|}{ Model } & $\begin{array}{c}\text { Sum of } \\
\text { Squares }\end{array}$ & Df & $\begin{array}{c}\text { Mean } \\
\text { Square }\end{array}$ & F & Sig. \\
\hline 1 & Regression & 20.659 & 4 & 5.165 & 9.146 & $.000^{\mathrm{b}}$ \\
& $\begin{array}{c}\text { Residual } \\
\text { Total }\end{array}$ & $\begin{array}{c}64.938 \\
\text { Th.597 }\end{array}$ & 115 & .565 & & \\
\hline
\end{tabular}

Source: Primary data examined

Based on the results table 14 then if probability (sig) $>0.05$ or $\mathrm{F}$ arithmetic $<\mathrm{F}$ table then $\mathrm{Ho}_{\mathrm{o}}$ is not rejected, if probability $(\mathrm{sig})<0.05$ or $\mathrm{F}$ count $>\mathrm{F}$ table then $\mathrm{H}_{\mathrm{o}}$ rejected, which results in table above sig $=0.000<0.05$, so the $\mathrm{Ho}_{\mathrm{o}}$ is rejected, which means that the variable - independent variables together - the same effect on the dependent of variable. 
Individual Parameter Significance test (test statistic t)

Table 15.

Statistics test $\mathbf{t}$

Coefficients $^{\mathrm{a}}$

\begin{tabular}{|c|c|c|c|c|c|c|c|}
\hline \multirow[b]{2}{*}{ Model } & \multicolumn{2}{|c|}{$\begin{array}{l}\text { Unstandardized } \\
\text { Coefficients }\end{array}$} & \multirow{2}{*}{$\begin{array}{c}\begin{array}{c}\text { Standardiz } \\
\text { ed } \\
\text { Coefficient } \\
\text { s }\end{array} \\
\text { Beta } \\
\end{array}$} & \multirow[b]{2}{*}{$\mathrm{T}$} & \multirow[b]{2}{*}{ Sig. } & \multicolumn{2}{|c|}{$\begin{array}{l}\text { Collinearity } \\
\text { Statistics }\end{array}$} \\
\hline & B & Std. Error & & & & $\begin{array}{l}\text { Toleran } \\
\text { ce }\end{array}$ & VIF \\
\hline (Constant) & .914 & .456 & & 2.007 & .047 & & \\
\hline $\begin{array}{c}\text { The } \\
\text { independence } \\
(\mathrm{X} 1)\end{array}$ & .360 & .113 & .368 & 3.191 & .002 & .496 & 2.014 \\
\hline $\begin{array}{c}\text { Professionalism } \\
\text { (X2) }\end{array}$ & .309 & .119 & .315 & 2.590 & .011 & .447 & 2.239 \\
\hline Ethics (X3) & .309 & .106 & .311 & 2.909 & .004 & .576 & 1.737 \\
\hline Integrity (X4) & -.235 & .171 & -.248 & -1.376 & .172 & .203 & 4.931 \\
\hline
\end{tabular}

Source: Primary data examined

1. In the above table of significant variables $\mathrm{X}_{1}=0.002<0.05$ so that $\mathrm{H}_{0}$ is rejected

2. In the above table of significant $\mathrm{X}_{2}=0.011<0.05$ so that $\mathrm{H}_{0}$ is rejected,

3. In the table above sig $\mathrm{X}_{3}=0.004<0.05$ so that $\mathrm{H}_{0}$ is rejected,

4. In the above table of significant variable $\mathrm{X}_{4}=0172<0.05$ so that $\mathrm{H}_{0}$ is rejected,

$$
Y=0,914+0,360^{*} X 1+0,309^{*} X 2+0,309^{*} X 3-0,235^{*} X 4
$$

Where :
$Y:$ : Auditor Performance
$\mathrm{X}_{1}:$ The independence
$\mathrm{X}_{2}$ : Professionalism
$X_{3}:$ Professional ethics
$\mathrm{X}_{4}:$ Comprehension Integrity Client

\section{CONCLUSION AND RECOMMENDATIONS}

The results showed that:

1. Independence results prove positive effect on the performance of auditors it supports research K. M. Dinata (2013) and the study of Trisnaningsih (2007) which means that the higher independence of the auditor, the auditor's performance produced better.

2. Professionalism could be concluded positively affects the performance of auditor research is also consistent with the results of research Wahyudi and Aida (2006) which shows that the higher the level of professionalism of auditors then produced increasingly satisfactory performance.

3. Professional ethics can be summed positive effect on the performance of auditors these results together with the results of Kusuma (2012) and Herawaty and Susanto (2009) where the higher the auditor adhere to professional ethics then the resulting performance will be satisfactory.

4. Understanding of client integrity associated with GCG results showed that negative and no significant effect on the performance of auditors and the results of this study are consistent with Trisnaningsih (2007) are of the opinion that a negative or no significant effect on the

Blasius Febriyanto Trisno Saputro and Dwi Asih Surjandari: The Influence of Application System Quality Control in The Performance of Auditors (Empirical Studies) ABC Kap in South Jakarta in 2009 - 2013 
performance of auditors in which the auditor weak understanding of client integrity in carrying out the profession audit has put forward the concept GCG then the resulting performance will decline in performance

Research limitations

1. Object fairly limited research that professional auditor in public accounting firms and only a small part of the Quality Control System in which researchers try to put more emphasis on four variables.

2. Control is crucial that it is still not able to walk properly so it remains to be demonstrated and also the existence of free market AFTA in 2015 with the principle of financial governance based GCG then the variable independence, professionalism, professional ethics and understanding of client integrity

\section{Suggestions}

1. For Companies and Auditors With the effect of the application of Quality Control System in the independence, professionalism and ethics of the profession, the KAP. ABC still retain an auditor in the performance improved, although still weak in understanding the integrity of client KAP variables. $A B C$ living increase in the future in order to be able to support a positive performance that is useful to improve the quality of auditors that are reliable and able to compete in the AFTA, 2015.

2. For Further Research, this study also gives effect to the subsequent researchers who want to conduct similar research as the author did. Subsequent research could specify other factors that could increase the independence, professionalism, professional ethics and integrity of the client's understanding of the performance of the auditor because there are variable in quality control systems that have not been researched and developed the hypothesis.

\section{REFERENCES}

Arens, Alvin A, Elder, Randal J, Besley, Mark S. (2005). Auditing and Assurance Services. Prentice Hall International, New York.

Anonymous. (2000). Statemenet on Quality Control Standars No. 4 - System of Quality. Journal of Accountancy, 189(5), pp: 125.

Ariyanto, Dodik dan Ardani Mutia Jati. (2010). Pengaruh Independensi, Kompetensi, dan Sensitivitas Etika Profesi terhadap Produktivitas Kerja Audit Eksternal (Studi Kasus pada Auditor Perwakilan BPK RI Provinsi Bali). Jurnal Akuntansi dan Bisnis Volume 20 (2). H; 21.

Brandon, Duane M. (2010). External Auditor Evaluations of Outsourced Internal Auditors, Auditing: A Journal of Practice \& Theory, 29 (2), pp: 159-173.

Bowlin, Kendall O, Jessen, L Hobson, dan M. David, Piercey. (2013). The Effects of Auditor Rotation, Profesional Skepticism, and Interaction with Managers on Audit Quality.

Cezair, Joan A. (2010). How Independence Can an External Auditor Really Be?. Internal Auditing, (2592), pp: 3-8.

Christiawan, YJ. (2002). Kompetensi dan Independensi Akuntan Publik: Refleksi Hasil Penelitian Empiris. Journal Directory: Kumpulan Jurnal Akuntansi dan Keuangan Unika Petra. Vol. 4 / no. 2.

Clark, Colin dan Key Levy. (2012). Improving Accountability in the Solomon Island: A Review of Auditor-General Enabling Legislation. Asia Pacific Law Review, 20 (1), pp :45-62

Blasius Febriyanto Trisno Saputro and Dwi Asih Surjandari: The Influence of Application System Quality Control in The Performance of Auditors (Empirical Studies) ABC Kap in South Jakarta in 2009 - 2013 
Curtis, Mary B, Teresa L. Conover, Lawrence C. Chui. (2012). A Cross-Cultural Study of the Influence of Country of Origin, Justice, Power Distance, and Gender on Ethical Decesion Making. Journal of Internasional Accounting Research Volume 11 (1). H: 5-34.

Friska, Novanda. (2012). Pengaruh Profesionalisme Auditor, Etika Profesi dan Pengalaman Auditor terhadap Pertimbangan Tingkat Materialitas Skripsi Fakultas Ekonomi Universitas Negeri Yogyakarta.

Flint, David. (1998). Philosophy and Principles of Auditing: an Introduction, London: Mac Millan Education LTD.

Gunawan. (2006). Pengaruh Profesionalism dan Komitmen Organisasi terhadap Kinerja Internal Auditor dengan Kepuasan Kerja Sebagai Variabel Intervening (Studi Empiris pada Internal Auditor PT. Bank ABC). Tesis Universitas Diponegoro.

Gusti Ayu Novi Anggraeni, I Dewa Nyoman Badera. (2013). Pengaruh Penerapan Sistem Pengendalian Mutu pada Kinerja Auditor di Kantor Akuntan Publik Provinsi Bali, E-Jurnal Akuntansi Universitas Udayana, 5-2 2013, Hal: 307-325.

Ghozali, Imam. (2013). Aplikasi Analisis Mutivariate dengan Program SPSS 2. Edisi 7. Semarang: Badan Penerbit Universitas Diponegoro.

Halim, Abdul, (2008), Auditing (Dasar - Dasar Audit Laporan Keuangan). Jilid 1, Edisi Keempat. Yogyakarta: UPP STIM YKPN.

Herawatidan Susanto. (2009). Pengaruh Profesionalisme, Pengetahuan Mendeteksi Kekeliruan dan Etika Profesi terhadap Pertimbangan Tingkat Materialitas Akuntan Publik Jurnal Akuntansi dan Keuangan Vol. 11 No. 1.

Ikatan Akuntan Indonesia.(2012). Pedoman Standar Akuntansi Keuangan. Jakarta: Salemba Empat.

Ikatan Akuntan Indonesia.(2013). Majalah Akuntan Indonesia. Diakses pada 8 Desember 2014 dari worl wide web:http.www.iaiglobal.co.id.

Institut Akuntan Publik Indonesia, (2013). Standar Profesional Akuntan Publik. Jakarta: Salemba Empat.

Institut Akuntan Publik Indonesia. (2010). Sistem Pengendalian Mutu, Buletin Akuntan Publik, Edisi 12 Tahun II Desember 2010, 12(2): h:2-11

Komite Nasional Kebijakan Governance (KNKG). (2006). Pedoman Umum Good Corporate, Governance Indonesia. Jakarta

Kompiang Martina Dinata Putrid dan I.D.G Dharma Saputra. (2013). Pengaruh Independensi, Profesionalisme, dan Etika Profesi terhadap Kinerja Auditor pada Kantor Akuntan Publik di Bali. E-Jurnal Akuntansi Universitas Udayana 4.1:39-53

Kranacher, Mary-Jo. (2012). Promoting Auditor Independence: Overcoming Conflict of Interest: Certified Public Accountant. The CPA Journal, 82(5), pp: 80.

Mahsun, Mohammad, Firma Sulistyowati dan Heribertus A.P. (2007). Akuntansi Sektor Publik. Edisi Kedua. BPFE: Yogyakarta.

Mautz, R. K. dan Sharaf Hussein A. (1993). The Philosophy of Auditing. United States of America: American Accounting Association.

Blasius Febriyanto Trisno Saputro and Dwi Asih Surjandari: The Influence of Application System Quality Control in The Performance of Auditors (Empirical Studies) ABC Kap in South Jakarta in 2009 - 2013 
M. Ikbal, A. (2008), Penerapan Sistem Pengendalian Mutu pada Kantor Akuntan Publik Non-Afiliasi di Jakarta. Jurnal Akuntansi dan Keuangan , 7 (2): 186-195.

Murtantodan Marini. (2003). Persepsi Akuntan Pria dan Akuntan Wanita serta Mahasiswa dan Mahasiswi Akuntansi terhadap Etika Bisnis dan Etika Profesi Akuntan, Prosiding Simposium Nasional Akuntansi VI, Oktober, hlm.790-805.

Muhammad. (2008). Analisis Hubungan antara Profesionalisme Auditor dengan Pertimbangan tingkat Matrialitas dalam Proses Pengauditan Laporan Keuangan. Jurnal Penelitian \& Pengabdian dppm.uii.ac.id. Volume 6-Nomor 1-maret 2008.

Porter, Brenda, Simon, Jon, and Hatherly, David. (2003). Principles of External Auditing. England: John Wiley \& Sons.

Reza Minanda, Dul Muid. (2013), Analisis Pengaruh Profesionalisme, Pengetahuan Mendeteksi Kekeliruan, Pengalaman Bekerja Auditor. dan Etika Profesi terhadap Pertimbangan Tingkat Materialitas Akuntan Publik (Studi Empiris pada Auditor di KAP. Di Semarang). Diponegoro Journal of Accounting Vol.1 No.1 Tahun 2013.

Robbins, Stephen. (2001). Prilaku Organisasi: Konsep, Kontroversi, Aplikasi. Edisi Bahasa Indonesia. PT. Prenhallindo, Jakarta.

Saragi, Lili Marlin danVerani Carolina. (2010). Pengaruh Independensi Eksternal Auditor terhadap Kualitas Pelaksanaan Audit (Studi Kasus pada Beberapa Kantor Akuntan Publik di Bandung). Akurat Jurnal Ilmiah Akuntansi No. 2 Tahun ke-1 Mei-Agustus 2010.

Syamsudin, I Made Sudarma, Abdull Hamid Abbe, Mediaty. (2014). The Influences of Ethics, Independence, And Competence on The Quality of an Audit Through The Influence of Profesional Skepticism In BPK of South Sulawesi, Central Sulawesi and West Sulawesi. Hasanuddin Journal of Research in Business and Management Volume 2 Issue 7 (2014) pp: 08-14

Seruni, Puti Ayu. (2011). Pengaruh Pengalaman dan Pertimbangan Profesional Auditor terhadap Kualitas Bahan Bukti Audit yang Dikumpulkan (Studi Kasus pada KAP. di Bandung). Jurnal Ilmiah, Nomor 66 tahun 2 Septembe r- Desember 2011.

Sukriah, Ika, Akram, dan Biana Adhalnapty. (2009), Pengaruh Pengalaman Kerja, Independensi, Obyektivitas, Integritas, dan Kompetensi terhadap Kualitas Hasil Pemeriksaan. Simposium Nasional Akuntansi XII. Palembang.

Sukrisno Agoes. (2004). Auditing (Pemeriksaan Akuntan) oleh Kantor Akuntan Publik.

Trisnaningsih, Sri. (2007), Independemsi Auditor dan Komitmen Organisasi Sebagai Mediasi Pengaruh Pemahaman Good Governace, Gaya Kepemimpinan, dan Budaya Organisasi Terhadap Kinerja Auditor. Disampaikan pada Simposium Nasional Akuntansi $X$ di Universitas Hasanuddin, Makasar, 26-28 Juli 2007.

Utami, Ratna. (2009), Perbedaan Penerapan Etika Profesi Akuntan pada Perilaku Auditor Yunior dan Auditor Senior (Studi terhadap Auditor yang Bekerja pada KAP. di Malang), Jurnal Akuntansi Volume 6 (2). H:108-115.

Wati, Elya, Lismawati, NilaAprilla. (2010). Pengaruh Independensi, Gaya Kepemimpinan, Komitmen Organisasi, dan Pemahaman Good Governance terhadap Kinerja Auditor Pemerintah (Studi pada Auditor Pemerintah di BPKP Perwakilan Begkulu). Disampaikan pada Simposium Nasional Akuntansi XIII Purwokerto 2010 Universitas Jenderal Soedirman, Purwokerto.

Blasius Febriyanto Trisno Saputro and Dwi Asih Surjandari: The Influence of Application System Quality Control in The Performance of Auditors (Empirical Studies) ABC Kap in South Jakarta in 2009 - 2013 
Widyananda, Herman. (2008). Revitalisasi Peran Internal Auditor Pemerintah untuk Penegakan Good Governance di Indonesia. Publikasi, Seminar, Makalah dan Sambutan. Universitas Padjajaran.

Wedemeyer, Phil D.(2010). A Discussion of Auditor Judgment as the Critical Component in Audit Quality - A Practitioner's Perspektive. International Journal of Disclosure and Governance, 7 (4), pp: 320-333. 